\title{
Selecting The New Government Centre of Brebes Regency to Increase the Local Development Equity
}

\author{
Hadi Wahyono*, Sariffuddin Sariffuddin \\ Department of Urban and Regional Planning, Diponegoro University, Indonesia
}

\begin{abstract}
The local government centre is an area that accommodates various local government activities, both administrative activities and services that meet the needs of the community. In Indonesia, form of the area is usually an office complex of executive institutions which is led by the head of the local government along with the local government apparatus, and the local legislative assembly. Besides having office facilities, the area is equipped with various public service facilities, such as commercials; trade and services; as well as education and health facilities. As a result, the area is not only a local government centre but also centres of service and local development growth. At this time, the government centre of the Brebes Regency has been able to become an important growth centre for the regency. Unfortunately, the area is only able to support development growth of the northern region of the regency, but it has not been able to encourage equitable development throughout all of the regency area. This study aims to determine a new location for the government centre of Brebes Regency. In contrast to other relocating of the local government centre aiming to resolve existing problems of the centre, the relocating centre of the Brebes Regency aims to increase the equitable distribution of local development. Taking into account the criteria of geographical conditions; conformity with spatial planning; land availability; social, cultural, and historical conditions; politics and security; facilities and infrastructure; and accessibility, as well as using the Analytical Hierarchy Process (AHP) method, the selected area is in the Bulakamba District, out of the 6 alternative districts assessed. This district has some advantages of its location in the middle region of the Brebes Regency, adequate spacious area, proper land ownership status and accessibility.
\end{abstract}

\section{Introduction}

The local government centre is an area that accommodates local government activities, both in the form of local government administrative activities and services to the community to meet the needs of the general public. The form of the centre generally takes an office area

* Corresponding author: hadi.wahyono@pwk.undip.ac.id 
consisting of offices of government institutions that carry out executive functions, consisting of offices of regional heads and offices of local government equipment agencies; as well as the office of the legislative body in the form of a regional legislative assembly [4, 6]. The offices of executive institutions can be in the form of a compact building, but can also be in the form of an office complex consisting of many buildings. In general, office buildings of executive institutions are separate from legislative office buildings [10].

Besides having various local government office facilities, the local government centre is usually equipped with various public service facilities, such as commercial offices; trade facilities and services; education and health facilities. This causes the function of the centre area not only to be a place for various local government activities, but to be a place for public service for local communities who are in conflict [3]. Consequently, the centre is the movement destination and the centre of concentration of population activity. As a result, the development and physical change of the centre takes place rapidly, so that it grows into a congested urban area, even with the dominance of activities that are public services [10].

Because it develops more rapidly than government activities, public service activities often dominate more than government activities. In some local government centres, this causes disruption to local government activities, for example traffic jams, noise, air pollution, and security disturbances [10]. These disturbances cause not only government activities to not run smoothly, but also can cause the area to become slum, and even lead to a decline in the dignity of the local government centre as a place where important powers should be respected in the local region [15].

In some local government centre areas, the disruption greatly affected the performance of local government. So, to overcome this problem, some local governments intend to move the area to another location that is more appropriate. The location chosen must meet various criteria as the local government centre. In reality, the removal of the central government is not merely an effort to resolve problems in the existing centre, but can have a wider influence, on various sectors, even related to the local political and socio-cultural interactions [10]. Therefore, the selection of new locations for relocating new central government locations does not merely take into account the criteria of providing space that can accommodate various government activities and public services, but more importantly is able to encourage the growth of political and social interaction, and even distribution of development.

According to Ishenda and Guoqing (2019), the local government centre as part of the local capital carries a mission not only as a centre for local government activities, but also as a centre for economic activity and even carrying out diplomatic missions that show the face of the region. If the local government centre is seen as an area that is able to show the authority of the local government, and is even able to show the identity of its locality, then the guests who visit will feel the atmosphere of authority and beauty of the locality.

According to Turner and Turner (2011), the local government centre is the location of the local government activities in, in its development can be transformed into a city that increasingly has the characteristics and levels of progress that meet the requirements to be classified as cities. If such a stage of development occurs, there is a dilemma because cities and regencies have the same level in terms of the administrative hierarchy of government. The order of the prevailing government system, raises the tendency that leads to the decision to move the location of the centre can be out of the local capital city where it was originally.

Turner and Turner (2011), revealed that the local government centre area is a place to carry out all matters relating to government, both political and administrative activities, as well as 
all activities relating to matters concerning power and governance. One of the objectives of the planned area is to improve the quality of services for the community where it cannot be separated from the role of the government itself in implementing it. The selected city must be able to carry out the main functions of a regional capital, namely as the administrative centre of the government, the centre of community services, and the centre of the development of the surrounding area.

The ability of a local government to develop its function as a centre for government administration is strongly supported by the local's ability to manage an existing government institutional system. Factors that can illustrate the ability of an area to become an administrative centre are the quality of human resources owned by the area, with the dependent ratio variable, namely the ratio between the number of unproductive age population and the number of productive age population. This variable is expected to describe the potential of a region's human resources needed in the management of the local government.

The number of educational, health, and worship facilities as well as the availability of transportation facilities, can be used to determine the availability of service facilities in support of improving overall community services. It means that the facilities are not only for fulfilling the government facilities, but also for supporting the growth of the area.

The ability of an area to develop the surrounding area can be done if the area has been able to pass the threshold of growth that is able to support their own needs. To be able to achieve this growth is supported by adequate economic conditions. In order to know the economic condition of the prospective regency capital, the variables taken are the amount of food crop production, fishery production, livestock population, and plantation production engaged in industry.

Meanwhile, according to Turner and Turner (2011), many things must be fulfilled in realizing good governance in an area, one of which is through the design aspect, namely through the design of the area of his administration. The area of government is a place to carry out all matters relating to government, both political and administrative activities, as well as all activities relating to matters concerning politics and government. One of the objectives of the planned area is to improve the quality of services for the community where it cannot be separated from the role of the government itself in implementing it. Many things must be fulfilled in realizing good governance in an area, one of which is through the design aspects, namely through the design of the area of his administration. According to Spate (1942), there are several factors and indicators to determine the location or area of a prospective regency capital.

Some of them are macro environmental factors, which are environmental encouragement both from within and from outside such as encouraging the availability of space or land to make the district capital as the centre of government, the centre of development control and growth. Trade and other social services centres certainly require large spaces or land because not only land is provided only for offices but also for the benefit of social economic activities.

The other factors are regional endowment factors, which are the availability of adequate human resources and potential natural resources and sufficient level of community knowledge as potential residents of the regency capital, while what is meant by potential natural resources is the availability of water sources, land and so forth.

Besides, cultural factors which include the nature and behavior of the community, customs that provide support for the determination of the local district capital. Moreover, some factors also determine the feasibility of the location of the capital city of the regency, 
namely the carrying capacity of nature as mentioned above, including land and water resources, easy access to services and availability of basic infrastructure such as existing highways so as to ease the burden of infrastructure financing and at the same time function with the start of the construction of government facilities within the local district capital. In Indonesia, in the era of autonomy, each local regions both cities and regencies, is given autonomous authority to regulate its own local region in order to realize its own regional development in order to realize regional development, both physical and non-physical in nature. In addition, it becomes important to be implemented in responding to regional autonomy, which prioritizes improving the quality of public services that are good for the community. Optimal public service is one of the factors that determines service satisfaction for the community. Often optimal service to the community cannot be met due to several reasons. In implementing optimal governance, it needs to be done on the basis of the proximity of services between the regional government and the community.

The removal of the central government in this context is defined as the removal of one of the very complex functions of the local region capital, one of which is the function of local government activities. Transferring government functions to the new location is an effort of the local government to help reduce pressure in the main city as well as to equalize development and add urban centres. The alternative of moving the central government is not only to create optimal services and government performance, but this policy is also able to become a strategy and as the beginning of the emergence of new cities in the planned area. Good governance will certainly be the desire of all parties, both bureaucrats and society. The quality of service provided by bureaucrats will determine community satisfaction. One important factor in the effort to provide good and more optimal services to the community is the aspect of ease of community accessibility to the Government Capital and connectivity to other regions.

Regarding the relocation of the local government centre, Brebes Regency is one of the regional governments in Indonesia that plans to move the regional government centre. The relocation of the Brebes Regency government centre is related to the economic downturn along the Pantura road due to the construction of the Trans-Java toll road and the lack of optimal service locations for the Brebes Regency government centre that currently exists. The removal of the central government will certainly have an impact on economic and social changes in the environment around the central Government Capital.

The lack of optimal services for the existing government centre and the economic downturn in the main route of the Brebes Regency have triggered the need to study alternative locations for moving the Brebes Regency Government Centre to another location, which is likely to cause several impacts, both regional development, social governance, politics, economy, environment and others. Economic impacts that may arise include; job opportunities, business and investment opportunities, as well as access to capital. Social impacts such as population, education, health, security and culture. Considering the above, the Brebes Regency Government, in this case the Brebes Regency Regional Secretariat in collaboration with the author of this article, conducted a research to determine the location of the new Brebes Regency government centre.

\section{Method for determining the location of the local government centre}


Method used in this research for determining the location of the local central government is Analytical Hierarchy Process (AHP). AHP is a decision support model developed by Thomas L. Saaty (1993). This decision support model will break down complex multifactor or multi-criteria problems into a hierarchy. According to Saaty, hierarchy is defined as a representation of a complex problem in a multi-level structure where the first level is the goal, followed by the level of factors, criteria, sub-criteria, and so on down to the last level of alternatives. With hierarchy, a complex problem can be broken down into groups which are then arranged into a hierarchical form so that the problem will appear more structured and systematic.

In the AHP method the following steps are taken:

1. Define the problem

In this stage we try to determine the problem we will solve clearly, in detail, and easily understood. From the existing problem, we try to determine a solution that might be suitable for the problem. The solution to the problem may be more than one. We will develop these solutions later in the next stage.

2. Create a hierarchical structure

After compiling the main objective as the top level, the hierarchy level below it will be arranged, which are criteria that are suitable for considering or assessing the alternatives we provide and determining those alternatives. Each criterion has a different intensity. The hierarchy continues with sub-criteria (if needed).

3. Make a pairwise comparison matrix.

The advantage of the AHP method is its ability to combine qualitative and quantitative elements. Quantification of qualitative matters is carried out by providing a pairwise comparison scale. Someone who will provide these perceptions must understand thoroughly about the elements being compared and their relevance to the intended purpose.

According to Saaty (1993), rating scales from 1 to 9 are the best based on RMS (Root Mean Square Deviation) and MAD (Median Absolute Deviation) values.

\section{Analysis of the determination of the local government centre}

The analysis of the transfer of the Brebes Regency government centre was carried out based on the Minister of Domestic Regulation No. 30 of 2012 concerning guidelines for naming regions, naming the capital, changing the name of the region, changing the name of the capital, and moving the capital. Specifically regarding the relocation of the capital city is regulated in Chapter II Article 7 to Article 11, where there are 7 main criteria for assessment (Article 9), namely (1) geographical conditions, (2) compliance with spatial planning, (3) land availability, (4) ) social, cultural and historical, (5) politics and security,

(6) Facilities and infrastructure, and (7) Accessibility. Furthermore, the discussion of each criterion will be explored in more depth in the discussion section. There are 4 candidate locations for the capital city of Brebes Regency, namely (1) Brebes City / existing location, (2) Sigempol Village, Brebes District (3) Banjaratma Village, and (4) Bulakamba Village.

Analysis of the central government relocation instrument of Brebes Regency is an analysis of the condition of the characteristics of the six alternative points of location of the central government relocation based on indicators regulated by Minister of Home Affairs Regulation No. 30 of 2012 concerning guidelines for naming regions, naming capitals, changing regional names, and moving capital. Measurements are made based on the scale of interests containing values 1 to 5, namely: 

1: Not important
2: Not important
3: Neutral (are equally important)
4: Somewhat important
5: Important

As explained in the work implementation approach, in the final section in the form of determining alternative locations, this study will use the AHP method. The analytical tool used is Expert Choice.

\subsection{Analysis of variable weights}

Each variable considered in the assessment of alternative locations for the removal of the central government has not yet been weighted. Therefore, in this study, the composer will carry out a weighting so that each variable will have a different effect depending on the scale of importance. This variable weight assessment is done based on the assessment of respondents through a questionnaire and then processed using the AHP method. Questionnaires were given to heads of agencies under the Brebes district government. They were asked to rate the importance of a variable by comparing one variable to another. The sample questionnaires that must be filled are presented in the following table:

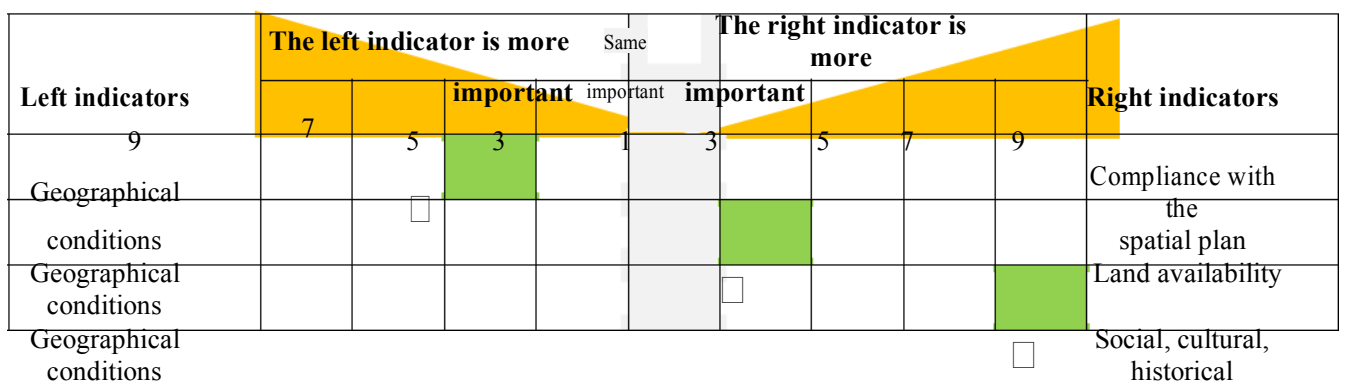

Fig. 1. The questionnaire assesses the weight of each indicator of the local government centre in Brebes Regency

From the comparisons between variables carried out by 6 respondents, it is known that the weight order of each variable to be used in the assessment of each variable using expert choice. From the processing of the questionnaire, the weight of each variable is obtained as follows: 
Table 1. Calculation of the weight of the assessment indicators

\begin{tabular}{|c|c|c|c|c|c|c|c|c|c|}
\hline \multirow{2}{*}{ Category } & \multicolumn{6}{|c|}{ Respondent } & \multirow{2}{*}{ Average } & \multirow{2}{*}{ Weight } & \multirow{2}{*}{ Rating } \\
\hline & 1 & 2 & 3 & 4 & 5 & 6 & & & \\
\hline Geographical & 0.27 & 0.01 & 0.07 & 0.06 & 0.02 & 0.04 & 0.08 & 7.80 & 7 \\
\hline Spatial plan & 0.07 & 0.03 & 0.07 & 0.49 & 0.08 & 0.06 & 0.14 & 13.60 & 4 \\
\hline Land aviability & 0.12 & 0.07 & 0.22 & 0.03 & 0.09 & 0.06 & 0.10 & 9.90 & 6 \\
\hline $\begin{array}{l}\text { Social, culture } \\
\text { and historical }\end{array}$ & 0.10 & 0.46 & 0.07 & 0.04 & 0.07 & 0.10 & 0.14 & 13.70 & 3 \\
\hline $\begin{array}{l}\text { Politics \& } \\
\text { security }\end{array}$ & 0.25 & 0.02 & 0.13 & 0.07 & 0.09 & 0.25 & 0.13 & 13.40 & 5 \\
\hline $\begin{array}{l}\text { Facilities and } \\
\text { infrastructure }\end{array}$ & 0.11 & 0.26 & 0.27 & 0.12 & 0.23 & 0.31 & 0.22 & 21.60 & 1 \\
\hline Accessibility & 0.09 & 0.14 & 0.17 & 0.21 & 0.42 & 0.19 & 0.20 & 20.00 & 2 \\
\hline Total & 1.00 & 1.00 & 1.00 & 1.00 & 1.00 & 1.00 & 1.00 & 100 & \\
\hline
\end{tabular}

\subsection{Analysis of the selection of alternative locations}

To find out the advantages of each alternative location, expert choice analysis will be compared from one location to another. In expert choice, this analysis is called head-tohead analysis by comparing each calculation parameter from one location to another.

\subsubsection{The City of Brebes (existing) analysis}

The condition and completeness of the facilities and infrastructure are the advantages of the City of Brebes compared to other locations. The City of Brebes, which is in the 1st order and is also the centre of the economy, currently makes this location has the most complete complete infrastructure and also good accessibility and is easy to reach both internally from Brebes Regency and from outside Brebes Regency. However, behind this easy accessibility, this city has a traffic jam. Furthermore, the large role of facilities and infrastructure as well as accessibility in the expert choice analysis was not matched by other parameters such as land area, land status and development opportunities. Therefore, this alternative location only won in 2 parameters, namely the parameters of completeness of facilities and infrastructure and accessibility. 


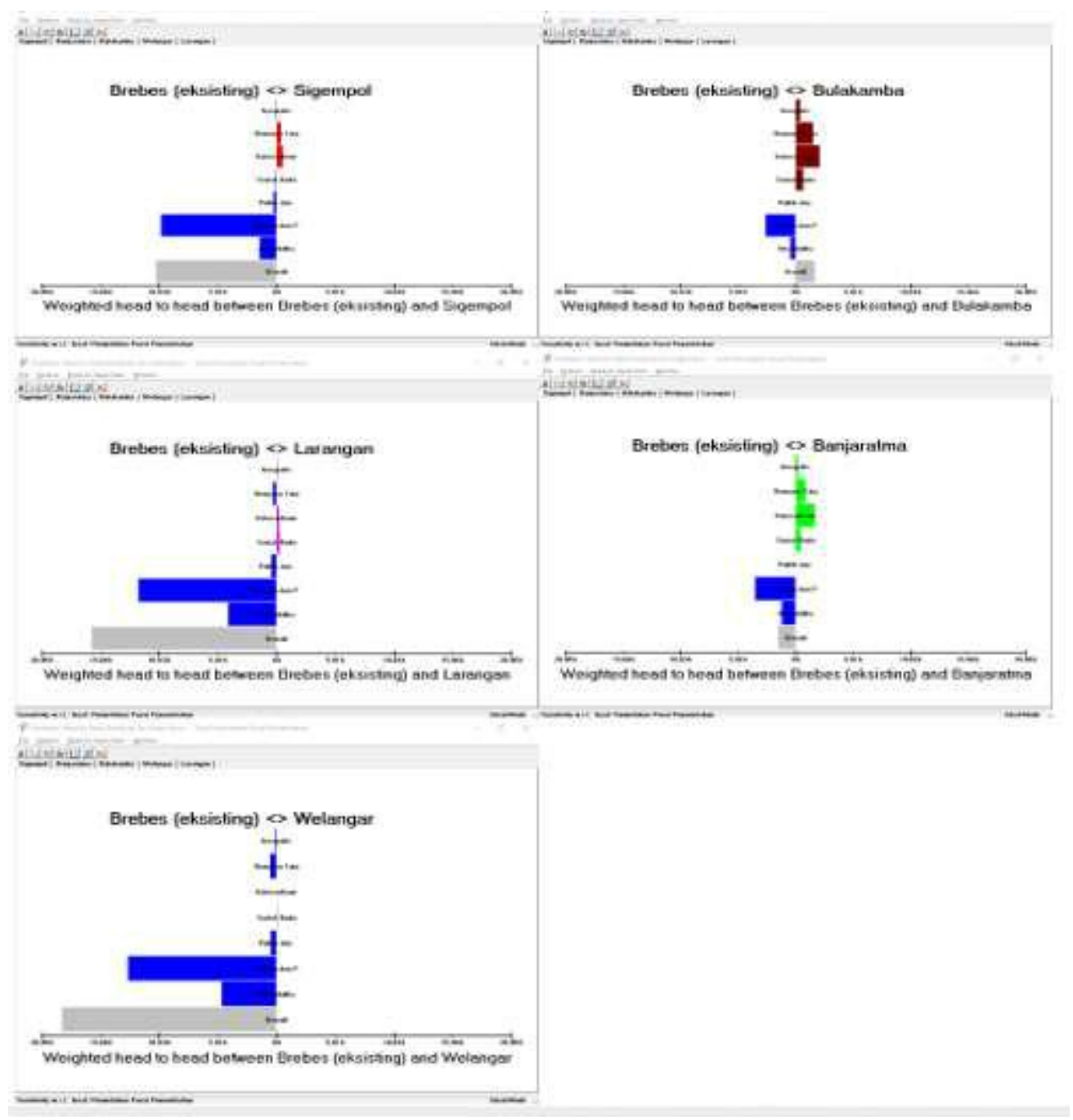

Fig. 2. Head to head analysis the City of Brebes versus other locations

Of the head to head analyzes above, only 1 analysis beat Brebes, namely Bulakamba District. In almost all analyzes with other locations, the City of Brebes won both large and small categories. For example, Kota Brebes is a small winner when compared to Banjaratma. This sub-district has a very large area of land that fills even more Banjaratma when compared to Brebes. Meanwhile, with other locations, the City of Brebes is superior for almost all parameters.

\subsubsection{Sigempol Sub District analysis}

Not much different from Brebes City, Sigempol Village is in the same sub-district, namely Brebes District. Its location in Brebes sub-district makes the completeness of the facilities and infrastructure at this location good, namely complete. However, for accessibility, it is easy to reach internally from Brebes Regency, especially in the City of Brebes and is 
relatively difficult if accessed from outside Brebes Regency, including if accessed from the southern part of Brebes Regency.

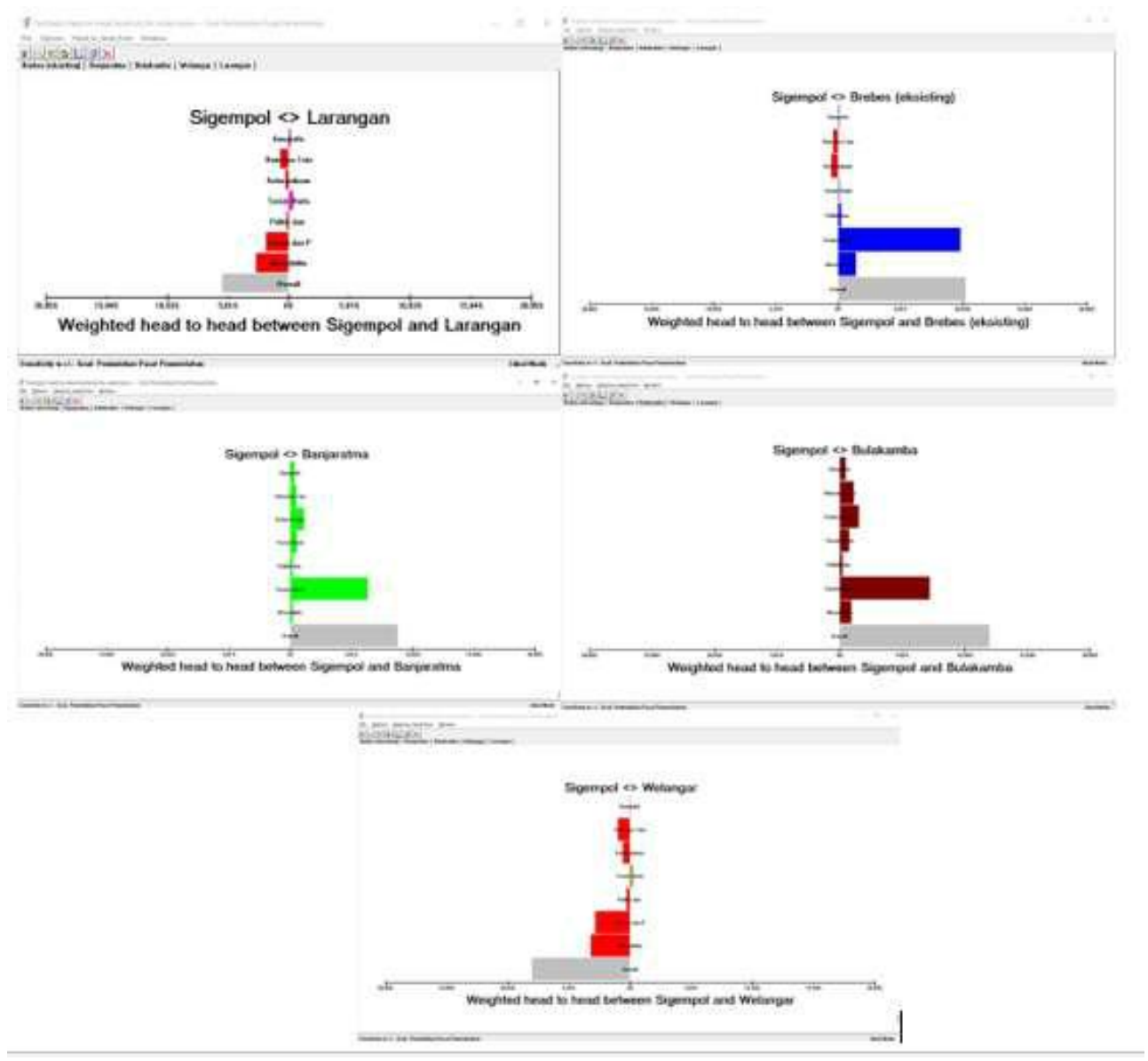

Fig. 3. Head to head analysis of Sigempol Sub District versus other locations

From the head to head analysis above, it is known that Sigempol Village is superior to Welangar and Larangan Villages, and not superior to other alternative locations. The superiority of Sigempol Village compared to Welangar and Larangan is in the completeness of facilities and infrastructure, accessibility and land status, namely the Brebes regency government certificate.

\subsubsection{Banjaratma Sub District analysis}

Banjaratma Sub District has great potential as the centre of government for Brebes Regency, it can even be said that Banjaratma is the main rival of Bulakamba Subdistrict in the entire analysis. Banjaratma is an ideal location in terms of all parameters except the land status. The land ownership is not yet owned by the Brebes Regency Government, so if you want to use this location, there is a need for a swap, making this location less eligible. In terms of facilities and infrastructure, accessibility to land area, all criteria are met and 
have a high value. In addition, this location is very strategic to provide a balance of development between northern Brebes and southern Brebes.

In the calculation of expert choice, it is known that Banjaratma is in second place under Bulakamba. This shows that almost all of the criteria meet only a few criteria that are under Bulakamba. Land status is a key criterion that makes the Banjaratma score below Bulakamba, even with the City of Brebes where the centre of the existing government is located. From the head to head analysis, it is known that Banjaratma is under the assessment of Bulakamba and Kota Brebes (existing). The less value of Bulakamba and Kota Brebes is due to the land status where from the weight value, this parameter has a high weight under the accessibility weight. The results of the head to head analysis are presented in the following figure

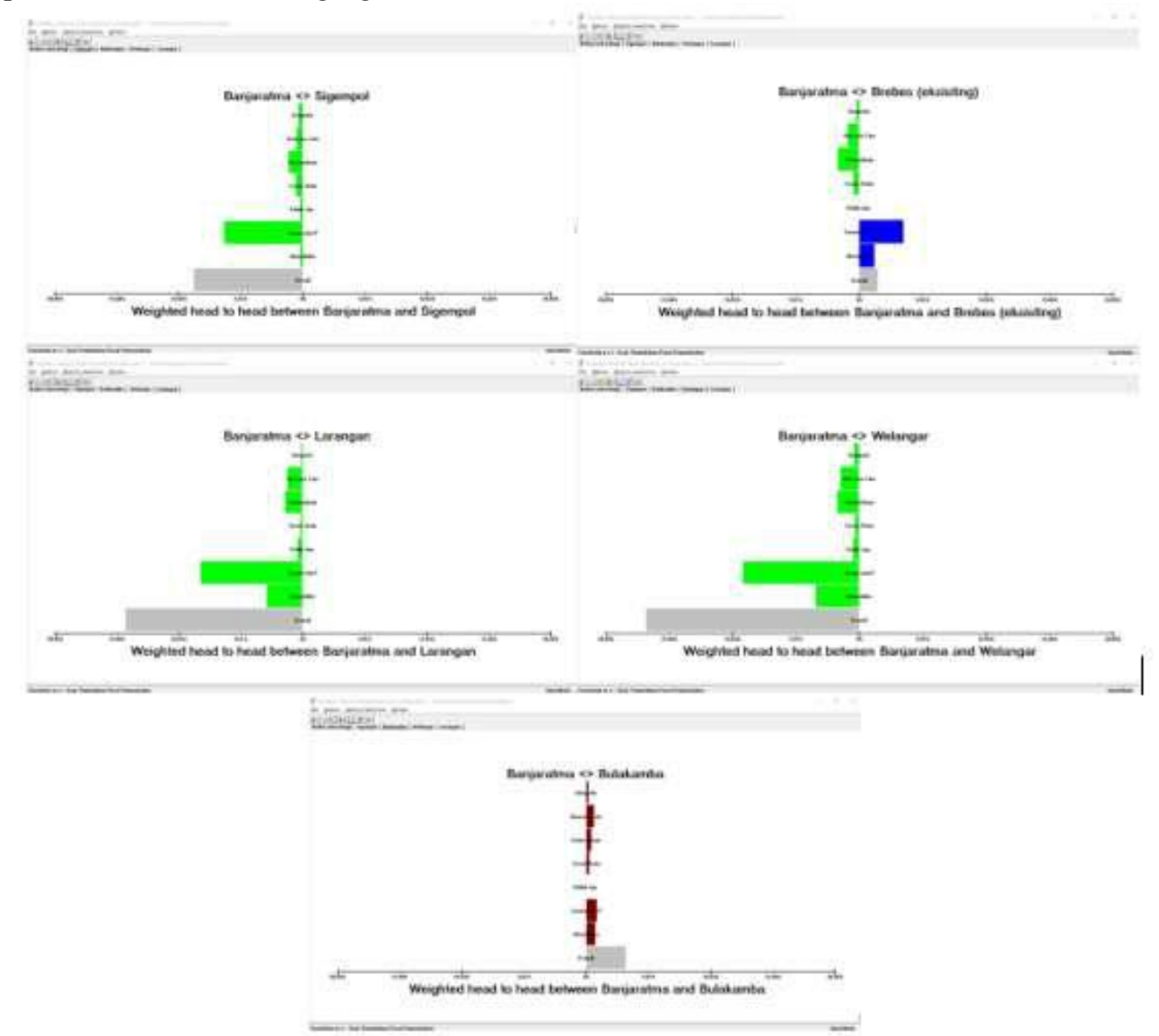

Fig. 4. Head to head analysis of Banjaratma Sub District versus other locations 


\subsubsection{Bulakamba Sub District analysis}

Bulakamba became the winner in the calculation of the alternative location for the transfer of the government centre in Brebes Regency. Bulakamba's main priorities are supported by land status, land area, availability of facilities and infrastructure as well as accessibility that is easily accessible from Brebes Regency and from outside Brebes Regency. The status of land that has been certified by the Brebes Regency Government with an area of more than 20 hectares is a big potential in the development of the central government because there is no need to carry out land acquisition. The existing budget can be used directly for development. The head to head analysis is presented in the following figure.

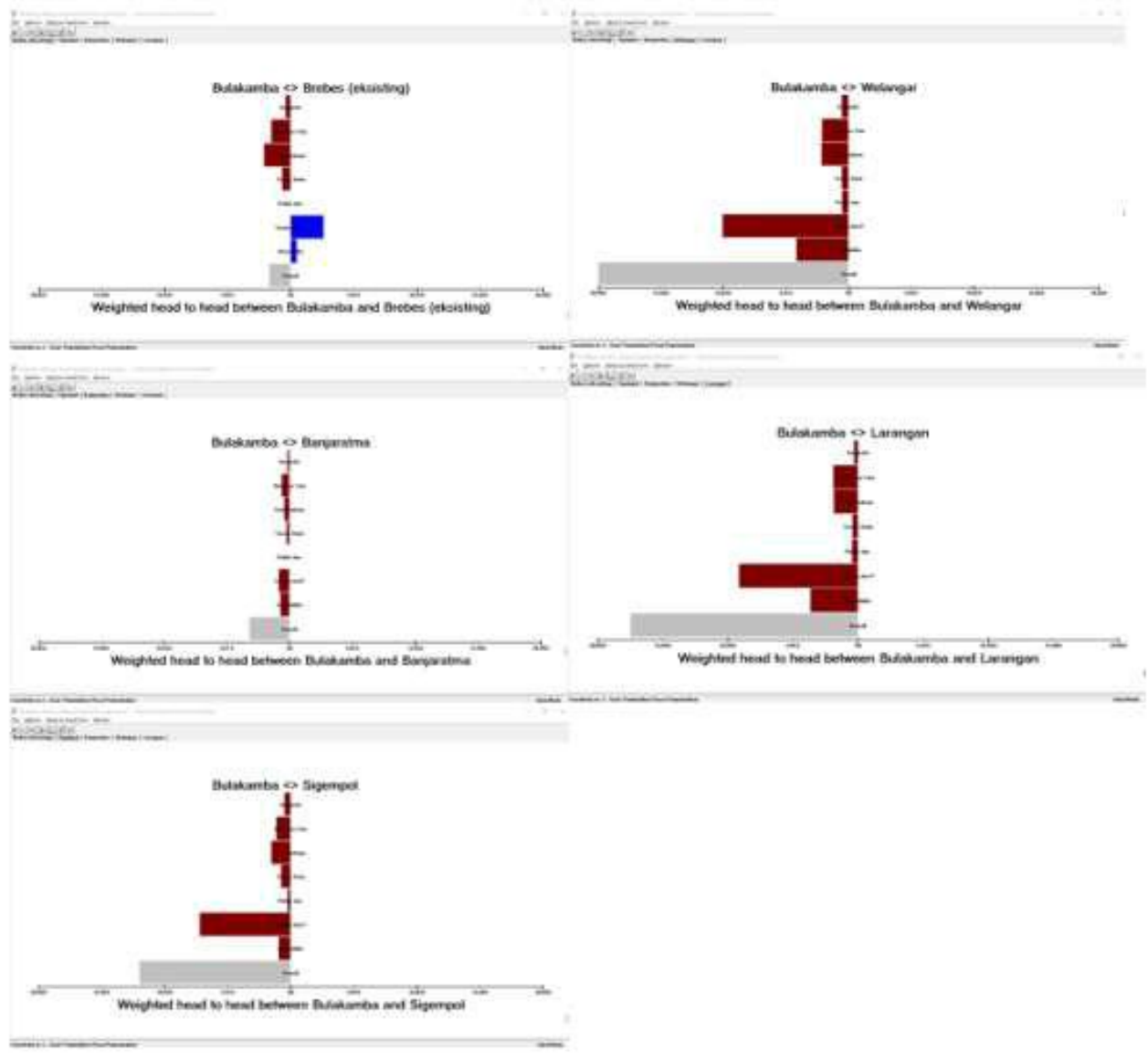

Fig. 5. Head to head analysis of Bulakamba Sub District versus other locations

\subsubsection{Welangar Sub District analysis}

What about Welangar Sub District? This sub district is located in Larangan Sub District with quite difficult access. To get to this area, you have to cross using a raft because the bridge that was previously built was damaged, washed away due to flash floods. In addition, the existing land is a former teacher bent which is currently being used by local residents as an agricultural area. Become the lifeblood of the local community. The head to head analysis is presented in the following figure. 


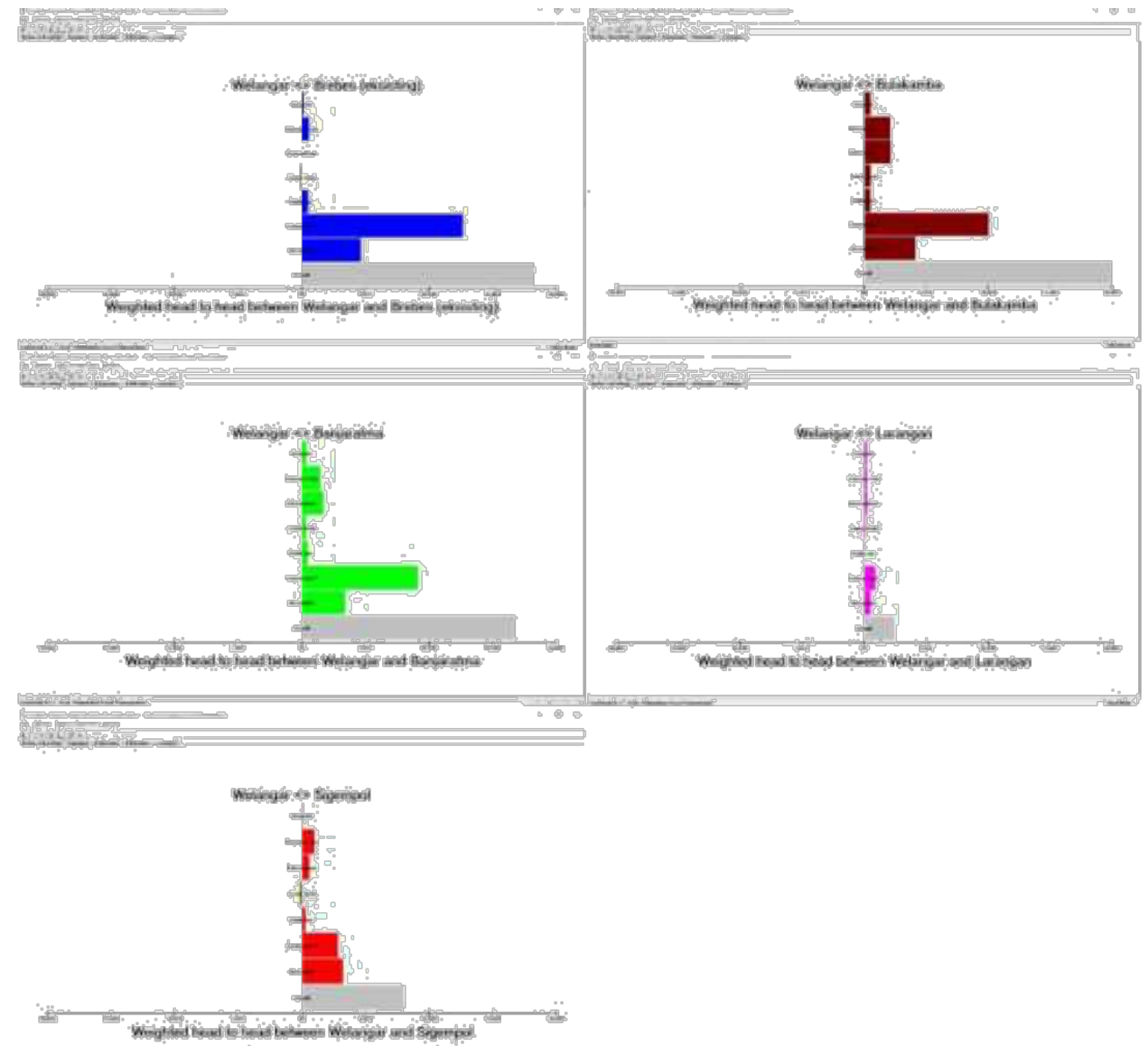

Fig. 6. Head to head analysis of Welangar Sub District versus other location

\subsubsection{Larangan Sub District Analysis}

The condition of Larangan Sub-District is not much different from Banjaratma, namely the status of the land has not been controlled by the local government of Brebes Regency. The land is still controlled by the local community. So that if this location is chosen, land acquisition must be carried out first. The existing land is non-productive agriculture, namely rainfed agriculture which harvests 2 times a year. When compared to other areas (in Brebes District), you can harvest 3-4 times a year. Accessibility is very good, as well as the condition and completeness of the facilities \& infrastructure is also very good. From the head to head analysis, this location is only better than Welangar Village, whereas when compared to other locations, it is still far from ideal conditions. The head to head analysis is presented in the following figure. 


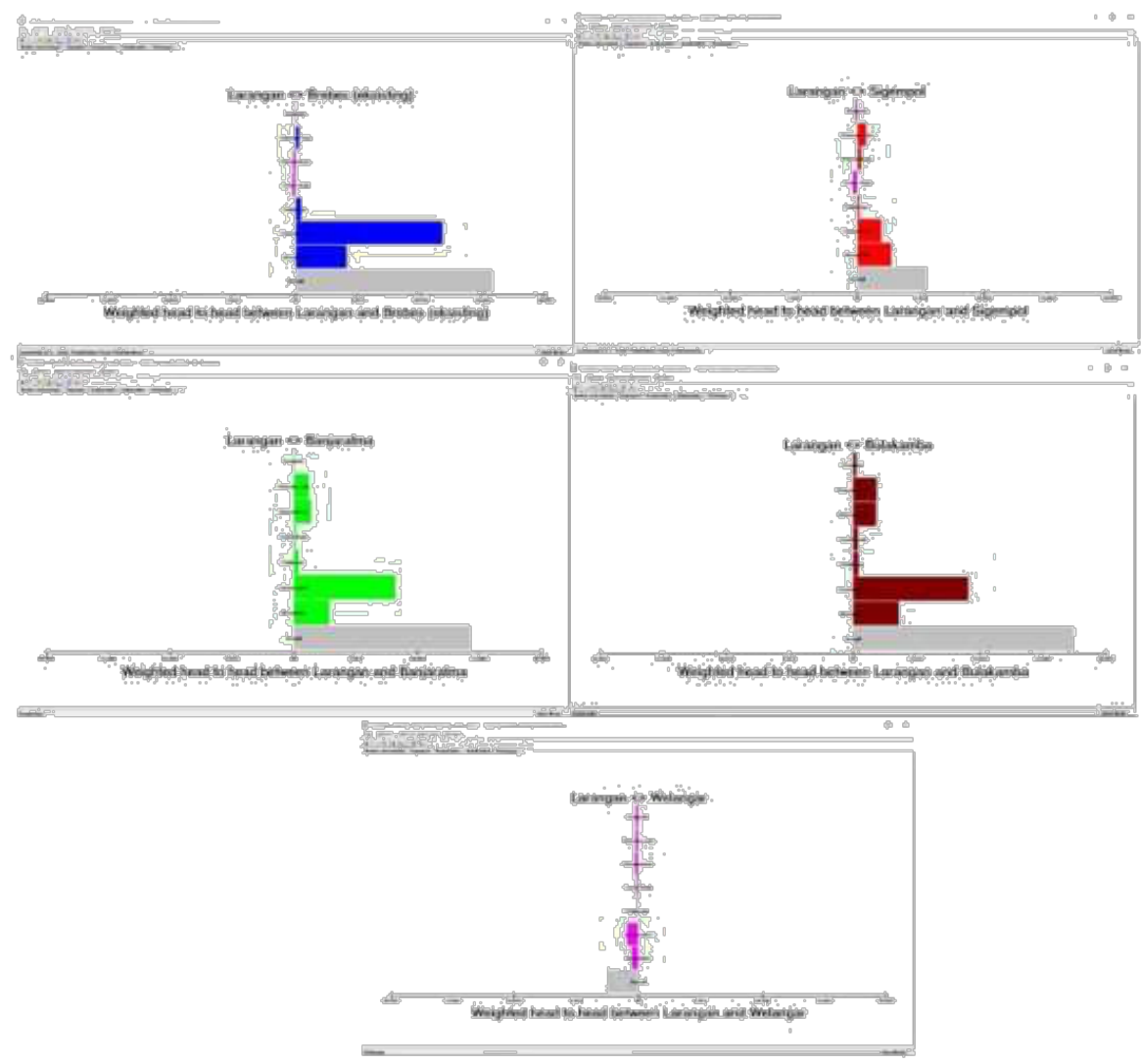

Fig. 7. Head to head analysis of Larangan Sub-District versus other locations

\subsection{The selected location point for the government centre of Brebes Regency}

The conclusion of the study on relocation of the central government of Brebes Regency was taken from all analyzes containing 7 variables, namely:

1. Geographical conditions

2. Conformity with the spatial plan

3. Land availability

4. Social, cultural and historical

5. Politics and security

6. Facilities and infrastructure

7. Accessibility

The main principle of central government is to provide services to the community at large so that the location must be easily accessible to the community. This affordability is not only seen from the distance but the availability of transportation facilities and infrastructure to facilitate public access. In addition, the physical condition of the micro area must also be considered as the basis for determining the feasibility of the location from the physical and building construction aspects. 


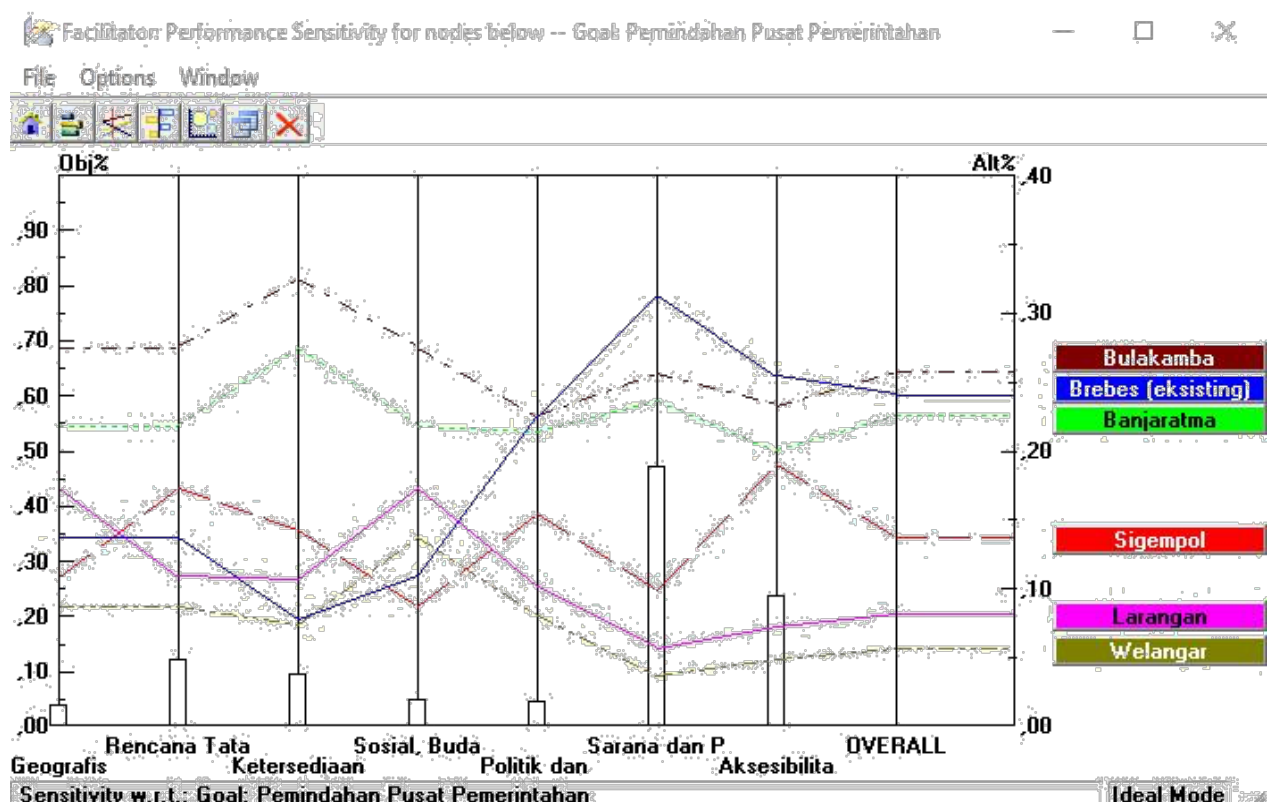

Fig. 8. The results of expert choice calculations for the selection of an alternative location

\section{Conclusions}

From the analysis that has been done, it can be concluded as follows:

1. The highest rank is Bulakamba

2. High ranking is Banjaratma

3. Medium rating, namely Brebes (existing)

4. Low rating is Prohibition

5. The low rank is Sigempol

6. Very low rank, namely Welangar

Bulakamba and Banjaratma (sugar factory) districts need serious attention. The variable determining the high value of Bulakamba is due to the status of the land that is already owned by the Brebes Regency Government, while for Banjaratma (sugar factory), the land is still owned by PTPN II, so a swap is required first. The land certificate in Bulakamba has become an administrative consideration. However, Bulakamba District is located on the northern coast of Java (Pantura) so that its services will be more easily accessible to people living in northern areas. The opposite condition is affordability of services for people in southern areas. If Bulakamba is used as the location for the relocation of the centre of government, it is very likely that this location will become the centre of new urban growth which needs to be accommodated and considered in the planning and development documents both regulated in the RTRW and RPJMD.

Banjaratma (sugar factory), in terms of location and accessibility, is an ideal location to provide affordable services for communities in the north and south. In addition, this alternative location also needs to be accommodated as a centre of government and a new urban centre if it is chosen as the centre of government. Banjaratma is considered ideal in terms of location and accessibility, not only based on the distance to the entire area in Brebes, but also from the relatively concentrated population density in the northern part of 
Brebes Regency. Different conditions with Sigempol and Brebes (existing conditions). The chair of this point has a good and high level of accessibility. However, the opportunities for developing office areas are limited. In Brebes (existing conditions) there must be land acquisition in areas with high land values. Meanwhile, Sigempol has a productive agricultural area around it. This main consideration must be considered in selecting an alternative location for the new government centre.

\subsection{The Concept of Development of the Local Government Centre of Brebes Regency}

The development of local government centre of Brebes Regency is inseparable from the chosen alternative locations as well as the existing location points that are still being utilized. Therefore, in this section, recommendations are given for developing the Brebes Regency government centre which contains three location points, namely (1) the selected location in Bulakamba District, (2) the current location, and (3) Sigempol which was previously planned as the centre.

Centre for developing economic potential: the proposed concept of developing the City of Brebes

The advantage of this location is that it is located in the city centre and also has the highest facilities and infrastructure compared to other alternative locations. Besides completeness of facilities and infrastructure, this location is also superior in locations where it has a good level of ease to be accessed from various places in Brebes Regency. Its location along the arterial road of the north coast of Java makes this area easier to reach, although behind that advantage is the congestion that often occurs in front of government offices.

Congestion that occurs not only occurs during Eid and long holidays but almost every day, especially at peak hours, namely in the morning at $07.00-09.00$ and in the afternoon starting at 15.00-16.30. The congestion is projected to continue and will become more congested if not controlled from the start. One of the generation (or contributors) of traffic jams is the location of the current government office at the centre of trade and services. The employees at the government office are also one of the contributors to the traffic jam in the form of employee generation in the morning and afternoon. This condition makes the level of comfort and work conducivity less optimal. In addition, the limited land makes the opportunity to develop a central government building not easy. Development of government centres is constrained by limited land and traffic conditions in the local trade area.

Referring to the existing potential, explained above, this location is very potential to be developed as one of the development of local economic potential. This form of economic potential development can be in the form of a gallery that displays the local economic potentials of Brebes Regency. This gallery is a promotional event and also a showroom, which presents local products in Brebes Regency. As an exhibition (exhibition) is strongly supported by the location and completeness of facilities including accommodations in the city centre. 


\subsection{Socio-cultural development centre: proposed concept for developing Sigempol}

Sigempol Village in Brebes Subdistrict, was originally planned as the centre of government, namely as a location for the removal of the current government centre. However, due to the low value of the feasibility of this location based on parameters used in the study of the removal of the central government, it is necessary to give direction to the concept of development. The size of the land around this location has the potential to develop a central government in this area, but the vast land area around the building is a productive rice field which is feared to affect agricultural productivity. As in the general development experience in Indonesia and other developing countries, that development externalities cannot be avoided, and it is a shadow development that continues to follow core development. The purpose of shadow development or development externalities is the emergence of development outside of planning and development as a direct or indirect result of the development of the market economy.

One direct consequence of development externalities is land conversion. If we pay attention, Sigempol Village is one of the productive agricultural areas, so if development is carried out in this area, it is feared that there will be a conversion of agricultural land to built up land and in a certain period of time will affect the productivity of the agricultural sector in Brebes Regency. Another consideration that must also be considered is the limited land area, which is $5.5 \mathrm{Ha}$. While the central government requires a minimum land area of 25 hectares to accommodate all government agencies at the district level. So that, directly or indirectly, if this location is used as the centre of government, it must free productive agricultural land to be conserved as an office area.

Referring to the above considerations, the team proposed the use of the Sigempol Village (existing building) as the socio-cultural centre of the community. Youth activities related to art, culture and social life can be centred in this area. It is very possible to develop it, considering that Brebes has great potential in the fields of culture, social organization and youth. This alternative concept can take advantage of existing buildings.

\subsection{Brebes Regency government centre: proposed Bulakamba Sub District development concept}

As explained in the analysis of the selection of the location of the central government in Chapter 6, the results of calculations show that Bulakamba is the most potential area to be used as the administrative centre of the Brebes Regency. The magnitude of this potential is mainly supported by the status of land that has been certified by the Brebes district government, sufficient land area and is on national roads / roads so that it is easily accessible from various locations both in Brebes Regency and from outside Brebes Regency. This proposed land as the centre of government is currently being used for rainfed agriculture and there is no technical irrigation.

Even though this area gets the highest score as the best alternative for the location of the central government, there are some things that must be considered and fulfilled. First, there is a need for specific and specific recommendations in the regional spatial plan and the medium-term development plan of the Brebes Regency which direct this location as the centre of the new government. This study can be used as input for the revised planning and development document in Brebes Regency. Second, detailed planning is needed in the form 
of a central government master plan. As the centre of the new government, it will certainly be an attraction for the surrounding activities. Growing economic activity that can be in accordance with the direction of the plan but may also not be in accordance with the plan or what is often referred to as development externalities. Therefore, if there is a detailed regional planning in the form of a master plan or a $3 \mathrm{D}$ area design it will be easier to direct development in this area.

\section{Acknowledgment}

The author expresses his gratitude to the Faculty of Engineering, Diponegoro University for the funding provided for this research.

\section{References}

1. Setyono, J., and Yunus, H.B., and Giyarsih, S. The spatial pattern of urbanization and small cities development in central java: a case study of Semarang-YogyakartaYurakarta region. Geoplanning: Journal of Geomatics and Planning, vol. 3, no. 1, pp. 53-66 (2016)

2. Ishenda, D.K., and Guoqing, S. Determinants in relocation of capital cities. Journal of Public Administration and Governance, Vol. 9, No. 4, 200-220 (2019)

3. Dascher, K. Are Politics and Geography Related?: Evidence from a Cross-Section of Capital Cities. Public Choice 105, 373-392 (2000)

4. Potts, D. Capital Relocation in Africa: The Case of Lilongwe in Malawi. The Geographical Journal, 151(2), (1985)

5. Shimamura, T., and Mizunoya, T. Sustainability Prediction Model for Capital City Relocation in Indonesia Based on Inclusive Wealth and System Dynamics. Sustainability 12 (10), 4336 (2020).

6. Spate, O. Factors in the Development of Capital Cities. Geographical Review, 32(4), 622-631 (1942)

7. Claval, P. The European system of capital cities. GeoJournal, 51(1/2), 73-81. Retrieved July 12, 2020, from www.jstor.org/stable/41147499 (2000).

8. Turner, S.C., and Turner, R.N. Capital cities: a special case in urban development. Ann Reg Sci 46, 19-35 (2011)

9. Wilcher, L. Capital Cities and Australian Progress. The Australian Quarterly, 6(23), 17-30 (1934)

10. Moser, S. Capital cities: Varieties and patterns of development and relocation, by Vadim Rossman, Journal of Urban Affairs, 41:4, 0 (2019).

11. Dascher, K. Capital cities: When do they stop growing?. Papers Reg Sci 81, 49-62 (2002)

12. Dascher, K. County capital cities, county public finance and county economic geography. Economics of Governance 5, 213-233 (2004). 
13. Spate, O. Factors in the Development of Capital Cities. Geographical Review, 32(4), 622-631 (1942)

14. Schatz, E. What Capital Cities Say About State and Nation Building, Nationalism and Ethnic Politics, 9:4, 111-140 (2004)

15. Turner, S.C., Turner, R.N. Capital cities: a special case in urban development. Ann Reg Sci 46, 19-35 (2011)

16. Swap, C. R. The Capital Relocation Issue in Alaska. Western Political Quarterly, 17(2), 213-234 (1964).

17. Vargas, R. V. Using the analytic hierarchy process (AHP) to select and prioritize projects in a portfolio. Paper presented at PMI ${ }^{\circledR}$ Global Congress 2010 - North America, Washington, DC. Newtown Square, PA: Project Management Institute. (2010)

18. Saaty, T.L. The Analytic Hierarchy Process. New York, USA: McGraw-Hill (1980) 
19. Saaty, TL.; Vargas, L.G. Models, Methods, Concept \& Aplications of The Analytic Hierarchy Process. Internationel Series in Operations Research \& Management Science. Second Edition. New York: Springer (1993). 